\title{
A Comparative Study on Wheat Production Technology Adopted by Indian and Afghan Farmers
}

\author{
Abdul Rashid Mukhtarzai, P. K. Chahal* and B. S. Ghanghas \\ Department of Extension Education, CCS HAU, Hisar, India \\ *Corresponding author
}

\section{Ke y w o r d s \\ Adoption, Wheat production technology, Productivity, Seed rate, Spacing, Seed treatment, Fertilizers, irrigation, Plant protection measures etc}

\section{Article Info}

Accepted: 26 July 2020 Available Online: 10 August 2020

\section{A B S T R A C T}

Wheat crop is adaptable to a wide range of soil and climatic conditions. The wheat crop is most successfully grown between the latitude of $30^{\circ} \mathrm{N}$ and $60^{\circ} \mathrm{N}$ and between $27^{\circ} \mathrm{S}$ and $40^{\circ} \mathrm{S}$. Wheat is grown in 218.54 million hectares with a production of 771.71 million tons of grain all over the world. India produces 98.61 million metric tons of wheat from 29.72 million hectare land with average productivity of $3318 \mathrm{~kg} /$ hectare (Director Report 2017-18) and 75 per cent of the wheat produced in India is used for the preparation of chapatti. Like India, wheat is also one of the main cereal crops for Afghan farmers because wheat is a staple food for Afghanistan. In Afghanistan, 1.63 million hectare area is under wheat cultivation and average production is $2210 \mathrm{~kg} / \mathrm{hectare}$ and total annual production is 3.61 million metric tons. Afghanistan faces annually around 2.4 million metric tons shortage of wheat which is compensated by importing from other countries (APR, MAIL, Afghanistan, 2018). Keeping in view the difference between wheat productivity of India and Afghanistan, this study was undertaken purposively with the specific objective because the researcher is sponsored by USA in Grain Research and Innovation (GRAIN) project. GRAIN project is exclusively based on increasing wheat production in Afghanistan by different ways and means of wheat production technologies. Two states from each country were selected for the study purposively representing both the countries for maximum wheat production. These were Punjab and Haryana from India and Herat and Nangarhar from Afghanistan. Hisar (Haryana), Mansa (Punjab) districts from India, Injil (Herat) and Behsood (Nangarhar) districts from Afghanistan were selected purposively because these were major wheat-growing districts in both the countries. Three villages were selected randomly from each district and thereby a total number of twelve villages were selected for the data collection. 15 wheat growers from each village were selected randomly and total number of 180 wheat growers was selected to constitute a sample of the study. The data were collected through pre-tested structured interview schedule. Seven important wheat production technological practices namely; preparation of land, seed rate, spacing, seed treatment, fertilisers, irrigation facilities and plant protection measures were considered under scientific wheat production practices. Adoption of these practices was found out by using different statistical tools. Weighted mean score of adoption of various practices in Afghanistan, ranged from 1.40 to 1.97. The recommended practices having highest mean score were time of sowing with rank I followed by irrigation requirement with rank II, while mean adoption score of various practices of wheat production technology in India ranged from 2.02 to 2.89 . Recommended practices having highest mean score were recommended varieties with rank I followed by preparation of land with rank II. Further, it was observed that majority of the respondents had low adoption level of wheat production technology of wheat in Afghanistan, while in India; majority of the respondents had medium adoption level about recommended wheat production technology. 


\section{Introduction}

Agriculture is a way of being a tradition that for centuries has shaped the thought, the outlook, the civilization and the economic life of people of India. India's record of growth in agriculture over the past four decades has been fairly impressive. Contribution of agriculture growth to overall progress has been wide extending. Increased productivity has helped to give food to the poor, enhanced farm profits and provided opportunities for both direct and indirect employment. The achievement of India's agriculture is attributed to a sequence of steps that led to the accessibility of farm technologies which brought about a dramatic increase in agricultural development. Future growth needs to be faster, more broadly distributed and better targeted. Wheat (Triticum aestivum) is an important staple food not only in India and Afghanistan but also in many developing and developed countries across the globe. It is a cool-season crop, widely cultivated under varied agro-ecological conditions and cropping systems throughout the world. On a global basis, wheat provides better nourishment than any other cereal food crop. The incorporation of dwarf genes in wheat created new varieties that changed the scenario of wheat cultivation all over the world. The semi-dwarf and high-yielding cultivars ushered in the "Green Revolution" by bringing about a phenomenal jump in production and productivity. Efforts to raise the yield level of wheat and finding ways to tackle the impeding factors affecting yield have been a major concern of all quarters. Hybrid wheat cultivars hold some promise for increasing yield and deserve further studies and refinements in the application. In Afghanistan, about 12 per cent of the land is arable and currently less than 6 per cent is available for cultivation that yields about 95 per cent of its needs in wheat. Erratic winter snows and spring rains are the only source of irrigation water and relatively machines are in little use, chemical fertilizers or pesticides put a constraint on the agricultural production in Afghanistan. The variety of the country's crops corresponds to its topography. The area around Kandahar, Herat, and the broad Kabul plain yield fruits of many kinds. Wheat is common to several regions and make up 80per cent of all grain production. Wheat is grown in 218.54 million hectares with a production of 771.71 million tons of grain all over the world. India produces 98.61 million metric tons of wheat from 29.72 million hectare land with average productivity of 3318 kg/hectare (Director Report 2017-18) and 75 per cent of the wheat produced in India is used for the preparation of chapatti. Wheat is also one of the main cereal crops for Afghan farmers because wheat is a staple food for Afghanistan. In Afghanistan, 1.63 million hectare area is under wheat cultivation and average production is $2210 \mathrm{~kg} /$ hectare and total annual production is 3.61 million metric tons. Afghanistan faces annually around 2.4 million metric tons shortage of wheat which is compensated by importing from other countries (APR, MAIL, Afghanistan, 2018). Thus, both in India and Afghanistan, agriculture is the main contributor to both the countries' economy and it also plays a significant role in the growth of socio-economic sectors of both the countries.

Keeping in view the difference between wheat productivity of India and Afghanistan, this study was undertaken purposively with the specific objective "A Comparative Study on Wheat Production Technology Adopted by Afghan and Indian Farmers" because the researcher is sponsored by USA under Grain Research and Innovation (GRAIN) project. GRAIN project is exclusively based on increasing wheat production in Afghanistan by different ways and means of wheat production technologies. 


\section{Materials and Methods}

The study was conducted in Haryana and Punjab states of India and Herat and Nangarhar provinces of Afghanistan purposively. Hisar (Haryana) and Mansa (Punjab) districts from India, Injil (Herat) and Behsood (Nangarhar) districts from Afghanistan were selected for the study because these are among major wheat growing districts in both the countries. Three villages were selected randomly namely; Ramgar, Phuluwala Dogra and Daska from Mansa district and Madha, Daulatpur and Ladwa from Hisar district of India. However, Banaghar, Chaharmisrh and Benigah from Behsood district and Naween-Olia, Qula-eFaraeeha and Sirasiabmukhtar from Injil district of Afghanistan comprising a total of twelve villages were selected randomly for the data collection on "Comparative analysis of wheat production technology adopted by Afghan and Indian farmers". Fifteen wheat growers were selected randomly from each selected village for interview. Forty-five wheat growers from each state were selected for the study. Thus, a total no of respondents from both the countries (India and Afghanistan) were 180. Various wheat production technological practices viz. preparation of land, seed rate, spacing, seed treatment, fertilizers, irrigation facilities, plant protection measures and storage practices were analyzed to compare their adoption level. The data were collected with the help of a well structured and pretested interview schedule comprising the items for assessment of their wheat production practices requirements and adoption level. The wheat production practices were computed with the statistical measures like frequency, percentages, weighted mean score, ranks etc.

To measure the adoption level, the farmers were requested to reply about the actual use of every recommendation adopted as full adoption, partial adoption and no adoption. To quantify the extent of adoption by the respondents, the score was assigned to each selected practice of wheat production technology on these different levels of adoption.

The obtained score was placed under three categories based on adoption level as 'full adoption', 'partial adoption', and 'no adoption' with the score 3, 2 and 1 respectively. The obtained score was then summed up both respondent wise as well as component wise. All the components of adoption were separately categorized into low, medium and high categories of adoption level based on the equidistant method of computing categories.

\section{Results and Discussion}

\section{Adoption level of the respondents about wheat production technology}

Adoption has been defined by Rogers and Shoemaker (1991) "as a decision to make full use of new ideas as the best course available". In the present study, it is operationalized as the continued use of the wheat production technology by the farmers of Punjab and Haryana states of India and Herat and Nangarhar provinces of Afghanistan.

\section{Overall adoption of the respondents about wheat production technology}

The data in the Table 1 shows that majority of the respondents in Afghanistan (87.77\%) had low level of overall adoption followed by 12.22 per cent had medium level of overall adoption of wheat production technology in wheat crop. In India, 64.44 per cent of the respondents had medium level followed by 21.11 per cent had low and 14.44 per cent of the respondents had high level adoption of wheat production technology in wheat crop. 
Similarly, Singh et al., (2014) reported that 56.87 per cent of the respondents had medium level of overall adoption about scientific wheat cultivation practices and Patodiya (2018) reported that 60.42 per cent of the respondents had medium level of overall adoption about scientific wheat cultivation practices.

Extent of practice-wise adoption of the recommended wheat production technology

Seven practices to determine the extent of adoption were preparation of land, seed rate, spacing, seed treatment, fertilizers, irrigation requirement and plant protection measures. The results are presented in Table 2 and 3 as below:

\section{Preparation of land}

From Table 2, it is revealed that in Afghanistan, 82.22 per cent of the respondents had no adoption followed by 15.55 per cent of them had partial and only 2.22 per cent of the respondents had full adoption about deep ploughing with soil turning plough followed by two harrowing and planking. About leveling of seed bed, 75.55 per cent of the respondents had partial adoption followed by 15.55 per cent of them had full adoption while, 8.88 per cent of them had no adoption about leveling of land for seed bed in wheat crop. In India (Table 3), great majority (83.33\%) of the wheat growers had full adoption followed by 16.66 per cent of them had partial adoption and none for no adoption of deep ploughing with soil turning plough followed by two harrowing and planking. As high as 96.66 per cent of the respondents had full adoption followed by 2.22 per cent of them had partial adoption and only 1.11 per cent of the respondents had no adoption about leveling of land for seed bed in wheat crop.
It can be said that wheat producing farmers in Afghanistan had very low adoption of deep ploughing with soil turning plough followed by two harrowing and planking and medium adoption of leveling for seed bed. While, Indian wheat growers had practiced all the recommendations of the wheat production technology and tillage operations like ploughing, harrowing and land leveling practices in wheat production.

Similar is the study conducted by Kumar (2019) that all of the respondents $(100.00 \%)$ had full adoption about deep ploughing with soil turning plough followed by two harrowing and planking. Moreover, again all of them fully adopted the land leveling and Meena (2012) reported that 70.00 per cent of wheat growers had fully adopted field preparation practices for wheat production.

\section{Seed rate (kg/acre)}

It was clear from Table 2 that in Afghanistan, great majority of the respondents $(92.22 \%)$ had no adoption followed by 5.55 per cent of them had partial and only 2.22 per cent of the respondents had full adoption of early/timely sown wheat seed rate (40 kg/acre). As high as, 96.66 per cent of the respondents had no adoption followed by 2.22 per cent of them had partial and only 1.11 per cent of the respondents had full adoption of late sowing wheat, seed rate $(50 \mathrm{~kg} / \mathrm{acre})$.

In India, Table 3 shows that 97.77 per cent of the respondents had full adoption followed by 1.11 per cent had partial and 1.11 had no adoption about early/timely sowing seed rate (40 kg/acre). Great majority of the respondents $(90.00 \%)$ had full adoption followed by 7.77 per cent of them had partial and only 2.22 per cent of the respondents had no adoption of late sowing seed rate (50 $\mathrm{kg} / \mathrm{acre}$ ). 
Similar findings were reported by Meena (2012) that 69.33 per cent of wheat growers had full adoption of recommended seed rate for wheat cultivation.

\section{Spacing}

The study indicated that in Afghanistan (Table 2), great majority of the respondents $(92.22 \%)$ had no adoption followed by 5.55 per cent of them had partial adoption and only 2.22 per cent of the respondents had full adoption of irrigated timely sowing $(20 \mathrm{~cm})$ spacing. Almost all of the respondents (97.77 $\%$ ) had no adoption followed by 2.22 per cent of them had partial adoption and none of the respondent answered for irrigated late sowing $(18 \mathrm{~cm})$ spacing. Again almost all of the respondents $(97.77 \%)$ had no adoption and only 1.11 per cent of them had full and partial adoption of rainfed timely sowing $(20 \mathrm{~cm})$ in wheat crop. In India (Table 3) as compare to Afghanistan, 97.77 per cent of the respondents had full adoption followed by 1.11 per cent of the respondents had partial and 1.11 per cent had no adoption of irrigated timely sowing $(20 \mathrm{~cm})$ spacing. 94.44 per cent of the respondents had full adoption followed by 3.33 per cent of them had no adoption and only 2.22 per cent of them had partial adoption of irrigated late sowing $(18 \mathrm{~cm})$ spacing. As high as of the respondents (95.55\%) had no adoption followed by 3.33 per cent of them had full adoption and 1.11 per cent of them had partial adoption of rainfed timely sowing $(20 \mathrm{~cm})$ spacing in wheat crop. The finding shows that in Afghanistan great majority of wheat growers had no adoption about timely sowing spacing where as in India; the farmers had almost full adoption of the same practice.

\section{Seed treatment}

It is revealed from Table 2 that in Afghanistan, more than half of the respondents $(57.77 \%)$ had no adoption followed by 36.66 per cent of them had partial adoption and only 5.55 per cent of the respondents had full adoption of wheat seed treatment. In India, from Table 3, it was reported that near to half of the respondents (47.77\%) had full adoption followed by 37.77 per cent of them had no adoption and 14.44 per cent of the respondents had partial adoption of seed treatment in wheat crop.

This shows that in Afghanistan, according to lack of knowledge and less access to seed treatment chemicals, they have low adoption of seed treatment. But in India, almost half of the wheat producing farmers fully adopted and understand the importance of seed treatment in wheat production technology which forced them to adopt it. Similarly, Meena (2012) reported that 71.33 per cent of wheat producing farmers had fully adopted seed treatment.

\section{Fertilizers}

The data presented in Table 2 indicated that in Afghanistan, majority of the respondents $(67.77 \%)$ had partial adoption followed by 16.66 per cent of them had no and 15.55 per cent of the respondents had full adoption about recommended dose of nitrogen (150 $\mathrm{kg} /$ acre). 51.11 per cent of the respondents had partial adoption followed by 41.11 per cent of them had full and 7.77 per cent of the respondents had no adoption of recommended dose of phosphorous (60 kg/acre). 94.44 per cent of the respondents had no adoption followed by 4.44 per cent of them had partial and only 1.11 per cent of the respondents had full adoption of recommended dose of potash (40 kg/acre) in wheat crop.

In India as compared to Afghanistan (Table 3), 66.66 per cent of the respondents had full adoption followed by 31.11 per cent of them had partial and 2.22 per cent of the 
respondents had no adoption of recommended dose of nitrogen $(150 \mathrm{~kg} / \mathrm{acre})$. Majority of the respondents $(76.66 \%)$ had full adoption followed by 21.11 per cent of them had partial and only 2.22 per cent of the respondents had no adoption of recommended dose of phosphorous (60 kg/acre). In case of potash 44.44 per cent of the respondents had no adoption followed by 38.88 per cent of the respondents had partial adoption and 16.66 per cent of the respondents had full adoption of recommended dose of potash (40 kg/acre) in wheat crop.

Similarly, Kumbhare and Singh (2011) reported that 66.66 per cent of wheat producing farmers fully adopted recommended fertilizer doses for wheat cultivation, whereas Patodiya (2018) found that 62.50 per cent of farmers had adopted recommended fertilizer application regarding scientific wheat cultivation practices and Kaushik et al., (2012) reported that the wheat yield in India declined due to conventional blanket fertilizer recommendations, leading to imbalance use of fertilizers and lower fertilizer use efficiency.

\section{Irrigation requirement}

As far as adoption of the irrigation requirement in wheat production is concerned, all the six critical stages of irrigation in wheat were studied. The study in Afghanistan (Table 2) had brought out that 46.66 per cent of the respondents had full adoption followed by 42.22 per cent of them had partial adoption and 11.11 percent of them had no adoption irrigation at crown root initiation stage (20-25 DAS). In case of irrigation at tillering stage, 52.22 per cent of the respondents had partial adoption followed by 28.88 per cent of them had full adoption and 18.88 per cent of the respondents had no adoption of irrigation at tillering stage (40-45 DAS). More than half of the respondents
(57.77\%) had partial adoption followed by 24.44 per cent had no adoption and 17.77 per cent of them had full adoption of irrigation at jointing stage (60-65 DAS). Half of the respondents $(50.00 \%)$ had partial adoption followed by 27.77 per cent had full adoption and 22.22 per cent had no adoption of irrigation at flowering stage (80-85 DAS). o 63.33 per cent of the respondents had partial adoption followed by 31.11 per cent of them had no adoption and only 5.55 percent of the respondents had full adoption of irrigation at milking stage (100-105 DAS). In case of irrigation at dough stage, 58.88 per cent of the respondents had partial adoption followed by 38.88 per cent of them had no adoption and only 2.22 percent of the respondents had full adoption (115-120 DAS) in wheat crop.

In India as compared to Afghanistan (Table 3 ), more than half of the respondents $(56.66 \%)$ had full adoption followed by 41.11 per cent had partial adoption and 2.22 per cent of them had no adoption of irrigation at crown root initiation stage (20-25 DAS). 53.33 per cent of the respondents had partial adoption followed by 45.55 per cent had full adoption and 1.11 per cent of them had no adoption of irrigation at tillering stage (40-45 DAS). Majority of the respondents $(80.00 \%)$ had partial adoption followed by 20.00 per cent had full adoption and none of the respondents answered for no adoption of irrigation at jointing stage (60-65 DAS). In case of irrigation at flowering stage, 83.33 per cent of the respondents had partial adoption followed by 14.44 per cent had full adoption and 2.22 per cent of them had no adoption of irrigation (80-85 DAS). Majority of the respondents (77.77\%) had partial adoption followed by 17.77 per cent had full adoption and 4.44 per cent of them had no adoption of irrigation at milking stage (100-105 DAS).78.88 per cent of the respondents had partial adoption followed by 12.22 per cent of them had full adoption and 8.88 per cent of the respondents 
had no adoption of irrigation at dough stage (115-120 DAS) in wheat crop.

Similarly, Singh et al., (2014) reported that 91.25 per cent of wheat growers had adopted first irrigation at 21 days after sowing. Wheat and paddy cultivation requires sufficient water but in India, water resources are under stress particularly in the area of wheat-paddy rotation. Luhach (2016) reported that irrigation was the main constraint faced by the farmers hence, intervention was needed to ease in having this input either subsidizing it or providing means of credit to enable farmers to keep their pumps working.

\section{Plant protection measures}

It is revealed from Table 2 that in Afghanistan, majority of the respondents (84.44\%) had no adoption followed by 14.44 per cent of them had partial adoption and only 1.11 per cent of the respondents had fully adopted chemical control of termite in wheat crop. Majority of the respondents (75.55\%) had no adoption of aphids-jassids followed by 21.11 per cent of them had partial adoption and only 3.33 per cent of the respondents had full adoption of chemical control of aphidjassids in wheat crop.

In case of chemical diseases control, 73.33 per cent of the respondents had no adoption followed by 24.44 per cent of them had partial adoption and only 2.22 per cent of the respondents had full adoption of chemical control of loose smut. About flag smut, majority of the respondents $(81.11 \%)$ had no adoption followed by 18.88 per cent had partial adoption and none of the respondents answered for full adoption of chemical control of flag smut. In case of powdery mildew, 67.77 per cent of the respondents had no adoption followed by 32.22 per cent of them had partial adoption and none of the respondents answered for full adoption of chemical control of powdery mildew. In case of rust, 68.88 per cent of the respondents had not adopted chemical control of yellow rust while, 30.00 per cent of them had partial adoption and only 1.11 per cent of the respondents had full adoption of chemical control of yellow rust. 93.33 per cent of the respondents had no adoption of chemical control of Karnal bunt followed by 6.66 per cent of them had partial adoption and none of the respondents answered for full adoption of Karnal bunt in wheat crop.

About chemical weed control in Afghanistan, majority of the respondents $(72.22 \%)$ had partial adoption of recommended dose of chemical control of broad leaf weeds followed by 22.22 per cent of them had no adoption and only 5.55 per cent of the respondents had full adoption. 65.55 per cent of the respondents had partial adoption about recommended dose of chemical control of grassy weeds followed by 30.00 per cent of them had no adoption and only 4.44 per cent of the respondents had full adoption of grassy weeds (Phlaris minor and wild oat). Regarding the recommended dose of chemical control for both broad and grassy leaf weeds, 68.88 per cent of the respondents had partial adoption while, 26.66 per cent of them had no adoption and 4.44 per cent of the respondents had fully adopted this technology in wheat crop.

In India, Table 3 shows that 45.55 per cent of the respondents had no adoption about chemical control of termite followed by 37.77 per cent of them had full adoption and 16.66 per cent of the respondents had partial adoption of termite control in wheat crop. 44.44 per cent of the respondents had no adoption of aphids-jassids followed by 36.66 per cent of them had full adoption and 18.88 per cent of the respondents had partial adoption of chemical control of aphid-jassids in wheat crop. 
Table.1 Distribution of the respondents according to overall adoption of wheat production technology $(n=180)$

\begin{tabular}{|l|l|l|l|l|l|}
\hline $\begin{array}{l}\text { Sr. } \\
\text { No. }\end{array}$ & Category & Frequency & Percentage & \\
\hline 1. & Low (Below 79) & 79 & 19 & 87.77 & Indianistan \\
\hline India & Medium (79 to 99) & 11 & 58 & 12.22 & 64.11 \\
\hline 3. & High (Above 99) & 0 & 13 & 0.00 & 14.44 \\
\hline Total & & $\mathbf{9 0}$ & $\mathbf{9 0}$ & $\mathbf{1 0 0 . 0 0}$ & $\mathbf{1 0 0 . 0 0}$ \\
\hline
\end{tabular}

Table.2 Extent of practice-wise adoption of wheat production technology by Afghan wheat growers $(n=90)$

\begin{tabular}{|c|c|c|c|c|c|c|c|c|}
\hline \multirow{3}{*}{$\begin{array}{l}\text { Sr. } \\
\text { No. }\end{array}$} & \multirow{3}{*}{\multicolumn{2}{|c|}{ Category }} & \multicolumn{6}{|c|}{ Level of Adoption } \\
\hline & & & \multicolumn{2}{|c|}{$\begin{array}{c}\text { Full } \\
\text { Adoption }\end{array}$} & \multicolumn{2}{|c|}{$\begin{array}{c}\text { Partial } \\
\text { Adoption }\end{array}$} & \multicolumn{2}{|c|}{ No Adoption } \\
\hline & & & $\mathrm{F}$ & $\%$ & $\mathrm{~F}$ & $\%$ & $\mathrm{~F}$ & $\%$ \\
\hline A. & \multicolumn{8}{|c|}{ Preparation of land } \\
\hline 1. & \multicolumn{2}{|c|}{$\begin{array}{l}\text { Deep plugging with soil turning plough followed by two } \\
\text { harrowing and planking }\end{array}$} & 2 & 2.22 & 14 & 15.55 & 74 & 82.22 \\
\hline 2. & \multicolumn{2}{|c|}{ Leveling for seed bed } & 14 & 15.55 & 68 & 75.55 & 8 & 8.88 \\
\hline B. & \multicolumn{8}{|c|}{ Seed rate (kg/acre) } \\
\hline 1. & \multicolumn{2}{|c|}{ Early /timely sown $-40 \mathrm{~kg}$} & 2 & 2.22 & 5 & 5.55 & 83 & 92.22 \\
\hline 2. & \multicolumn{2}{|c|}{ Late sown $-50 \mathrm{~kg}$} & 1 & 1.11 & 2 & 2.22 & 87 & 96.66 \\
\hline C. & \multicolumn{8}{|l|}{ Spacing } \\
\hline 1. & \multicolumn{2}{|c|}{ Irrigated timely sown $(20 \mathrm{~cm})$} & 2 & 2.22 & 5 & 5.55 & 83 & 92.22 \\
\hline 2. & \multicolumn{2}{|c|}{ Irrigated late sown $(18 \mathrm{~cm})$} & 0 & 0.00 & 2 & 2.22 & 88 & 97.77 \\
\hline 3. & \multicolumn{2}{|c|}{ Rainfed timely sown $(20 \mathrm{~cm})$} & 1 & 1.11 & 1 & 1.11 & 88 & 97.77 \\
\hline D. & \multicolumn{2}{|c|}{ Seed treatment } & 5 & 5.55 & 33 & 36.66 & 52 & 57.77 \\
\hline E. & \multirow{2}{*}{\multicolumn{2}{|c|}{$\begin{array}{l}\text { Fertilizers } \\
\text { Nitrogen }(150 \mathrm{~kg} / \mathrm{ac})\end{array}$}} & & & & & & \\
\hline 1. & \multirow{2}{*}{\multicolumn{2}{|c|}{$\begin{array}{l}\text { Nitrogen }(150 \mathrm{~kg} / \mathrm{ac}) \\
\text { Phosnhorous }(60 \mathrm{~kg} / \mathrm{ac})\end{array}$}} & 14 & 15.55 & 61 & 67.77 & 15 & 16.66 \\
\hline 2. & & & 37 & 41.11 & 46 & 51.11 & 7 & 7.77 \\
\hline 3. & \multicolumn{2}{|l|}{ Potash $(40$ kg/ac) } & 1 & 1.11 & 4 & 4.44 & 85 & 94.44 \\
\hline F. & \multicolumn{8}{|c|}{ Irrigation Requirement } \\
\hline 1. & \multicolumn{2}{|c|}{ Crown root initiation stage (20-25 DAS) } & 42 & 46.66 & 38 & 42.22 & 10 & 11.11 \\
\hline 2. & \multicolumn{2}{|c|}{ Tillering stage (40-45 DAS) } & 26 & 28.88 & 47 & 52.22 & 17 & 18.88 \\
\hline 3. & \multicolumn{2}{|c|}{ Jointing stage (60-65 DAS) } & 16 & 17.77 & 52 & 57.77 & 22 & 24.44 \\
\hline 4. & \multicolumn{2}{|c|}{ Flowering stage (80-85 DAS) } & 25 & 27.77 & 45 & 50.00 & 20 & 22.22 \\
\hline 5. & \multicolumn{2}{|c|}{ Milking stage (100-105 DAS) } & 5 & 5.55 & 57 & 63.33 & 28 & 31.11 \\
\hline 6. & \multicolumn{2}{|c|}{ Dough stage (115-120 DAS) } & 2 & 2.22 & 53 & 58.88 & 35 & 38.88 \\
\hline G. & \multicolumn{8}{|c|}{ Plant protection measures } \\
\hline \multirow[t]{2}{*}{1.} & \multicolumn{8}{|c|}{ Chemical control of insect - pest } \\
\hline & $\begin{array}{l}\text { Name of insect - } \\
\text { pest }\end{array}$ & Control measures & & & & & & \\
\hline i. & Termite & $\begin{array}{l}2 \text { ltr Chloropyriphos } 20 \mathrm{EC} \text { with } 2 \text { ltr. } \\
\text { water in } 20 \mathrm{~kg} \text { sand per acre }\end{array}$ & 1 & 1.11 & 13 & 14.44 & 76 & 84.44 \\
\hline ii. & Aphid-jassids & Use $400 \mathrm{ml}$ Malathion $50 \mathrm{EC}$ in $250 \mathrm{ltr}$. & 3 & 3.33 & 19 & 21.11 & 68 & 75.55 \\
\hline
\end{tabular}




\begin{tabular}{|c|c|c|c|c|c|c|c|c|}
\hline & & Water per acre & & & & & & \\
\hline \multirow[t]{2}{*}{2.} & \multicolumn{8}{|c|}{ Chemical disease control } \\
\hline & Name of diseases & Control measures & & & & & & \\
\hline i. & Loose smut & $\begin{array}{l}\text { Seed treatment with } 2 \text { gm Vitavax or } \\
\text { Bavistin or } 1 \mathrm{gm} \text { Raxil per kg seed }\end{array}$ & 2 & 2.22 & 22 & 24.44 & 66 & 73.33 \\
\hline ii. & Flag smut & $\begin{array}{l}\text { Seed treatment with } 2 \mathrm{gm} \text { Vitavax or } \\
\text { Bavistin per kg seed }\end{array}$ & 0 & 0.00 & 17 & 18.88 & 73 & 81.11 \\
\hline iii. & Powdery mildew & $\begin{array}{l}\text { Spray } 800 \text { gm Karathane or Sulfex in } 250 \\
\text { ltr. water per acre }\end{array}$ & 0 & 0.00 & 29 & 32.22 & 61 & 67.77 \\
\hline iv. & Rust & $\begin{array}{l}\text { Yellow rust-Spray } 200 \mathrm{ml} \text { Propacona-zole } \\
\text { Brown rust -Spray } 800 \mathrm{gm} \text { Mancozeb } 250 \\
\text { ltr. water/ acre }\end{array}$ & 1 & 1.11 & 27 & 30.00 & 62 & 68.88 \\
\hline v. & Karnal bunt & $\begin{array}{l}\text { Seed treatment with } 2 \mathrm{gm} \text { Thiram per } \mathrm{kg} \\
\text { seed }\end{array}$ & 0 & 0.00 & 6 & 6.66 & 84 & 93.33 \\
\hline \multirow[t]{2}{*}{3.} & \multicolumn{8}{|c|}{ Chemical weed control } \\
\hline & Name of weed & Control measures & & & & & & \\
\hline i. & Broad leaf weed & $\begin{array}{l}\text { Spray } 250 \mathrm{~g} 2,4-\mathrm{D} \text { or } 8 \mathrm{~g} \text { Metsulfuron or } \\
20 \text { gm Affinity in } 250 \text { ltr. of water per acre }\end{array}$ & 5 & 5.55 & 65 & 72.22 & 20 & 22.22 \\
\hline ii. & $\begin{array}{l}\text { Grassy weeds } \\
\text { (Phlarisminor \& } \\
\text { wild oat) }\end{array}$ & $\begin{array}{l}\text { Spray } 160 \mathrm{gm} \text { Topik or } 13 \mathrm{gm} \text { Leader or } \\
400 \mathrm{ml} \text { Axial in } 250 \mathrm{ltr} \text {. of water per acre }\end{array}$ & 4 & 4.44 & 59 & 65.55 & 27 & 30.00 \\
\hline iii. & $\begin{array}{l}\text { Broad leaf } \\
\text { weed+Grassy leaf } \\
\text { weeds }\end{array}$ & $\begin{array}{l}\text { Spray } 16 \text { gm Total or } 160 \text { gm Atlantis or } \\
160 \text { gm Vesta in } 250 \text { ltr. water per acre }\end{array}$ & 4 & 4.44 & 62 & 68.88 & 24 & 26.66 \\
\hline
\end{tabular}

Table.3 Extent of practice-wise adoption of wheat production technology by Indian wheat growers $(n=90)$

\begin{tabular}{|c|c|c|c|c|c|c|c|}
\hline \multirow{3}{*}{$\begin{array}{l}\text { Sr. } \\
\text { No. }\end{array}$} & \multirow{3}{*}{ Particulars } & \multicolumn{6}{|c|}{ Level of Adoption } \\
\hline & & \multicolumn{2}{|c|}{$\begin{array}{l}\text { Full } \\
\text { Adoption }\end{array}$} & \multicolumn{2}{|c|}{$\begin{array}{l}\text { Partial } \\
\text { Adoption }\end{array}$} & \multicolumn{2}{|c|}{$\begin{array}{l}\text { No } \\
\text { Adoption }\end{array}$} \\
\hline & & $\mathrm{F}$ & $\%$ & $\mathrm{~F}$ & $\%$ & $\mathrm{~F}$ & $\%$ \\
\hline A. & \multicolumn{7}{|l|}{ Preparation of land } \\
\hline 1. & $\begin{array}{l}\text { Deep plugging with soil turning plough followed by } \\
\text { two harrowing and planking }\end{array}$ & 75 & 83.33 & 15 & 16.66 & 0 & 0.00 \\
\hline 2. & Leveling for seed bed & 87 & 96.66 & 2 & 2.22 & 1 & 1.11 \\
\hline B. & \multicolumn{7}{|l|}{ Seed rate (kg/acre) } \\
\hline 1. & Early /timely sown, $40 \mathrm{~kg}$ & 88 & 97.77 & 1 & 1.11 & 1 & 1.11 \\
\hline 2. & Late sown, $50 \mathrm{~kg}$ & 81 & 90.00 & 7 & 7.77 & 2 & 2.22 \\
\hline C. & \multicolumn{7}{|l|}{ Spacing } \\
\hline 1. & Irrigated timely sown $(20 \mathrm{~cm})$ & 88 & 97.77 & 1 & 1.11 & 1 & 1.11 \\
\hline 2. & Irrigated late sown $(18 \mathrm{~cm})$ & 85 & 94.44 & 2 & 2.22 & 3 & 3.33 \\
\hline 3. & Rainfed timely sown $(20 \mathrm{~cm})$ & 3 & 3.33 & 1 & 1.11 & 86 & 95.55 \\
\hline D. & Seed treatment & 43 & 47.77 & 13 & 14.44 & 34 & 37.77 \\
\hline E. & \multicolumn{7}{|l|}{ Fertilizers } \\
\hline 1. & Nitrogen $(150 \mathrm{~kg} / \mathrm{ac})$ & 60 & 66.66 & 28 & 31.11 & 2 & 2.22 \\
\hline
\end{tabular}




\begin{tabular}{|c|c|c|c|c|c|c|c|c|}
\hline 2. & \multicolumn{2}{|c|}{ Phosphorous (60 kg/ac) } & 69 & 76.66 & 19 & 21.11 & 2 & 2.22 \\
\hline 3. & \multirow{2}{*}{\multicolumn{2}{|c|}{$\begin{array}{l}\text { Potash }(40 \mathrm{~kg} / \mathrm{ac}) \\
\text { Irrigation Requirement }\end{array}$}} & 15 & 16.66 & 35 & 38.88 & 40 & 44.44 \\
\hline F. & & iirement & & & & & & \\
\hline 1. & \multicolumn{2}{|c|}{ Crown root initiation stage (20-2 } & 51 & 56.66 & 37 & 41.11 & 2 & 2.22 \\
\hline 2. & \multicolumn{2}{|c|}{ Tillering stage (40-45 DAS) } & 41 & 45.55 & 48 & 53.33 & 1 & 1.11 \\
\hline 3. & \multicolumn{2}{|c|}{ Jointing stage (60-65 DAS) } & 18 & 20.00 & 72 & 80.00 & 0 & 0.00 \\
\hline 4. & \multicolumn{2}{|c|}{ Flowering stage (80-85 DAS) } & 13 & 14.44 & 75 & 83.33 & 2 & 2.22 \\
\hline 5. & \multicolumn{2}{|c|}{ Milking stage (100-105 DAS) } & 16 & 17.77 & 70 & 77.77 & 4 & 4.44 \\
\hline 6. & \multicolumn{2}{|c|}{ Dough stage (115-120 DAS) } & 11 & 12.22 & 71 & 78.88 & 8 & 8.88 \\
\hline G. & \multicolumn{8}{|c|}{ Plant protection measures } \\
\hline \multirow[t]{2}{*}{1.} & \multicolumn{8}{|c|}{ Chemical control of insect - pest } \\
\hline & $\begin{array}{l}\text { Name of } \\
\text { insect-pest }\end{array}$ & Control measures & & & & & & \\
\hline i. & Termite & $\begin{array}{l}2 \text { ltr Chloropyriphos } 20 \text { EC with } 2 \text { ltr. } \\
\text { water in } 20 \mathrm{~kg} \text { sand per acre }\end{array}$ & 34 & 37.77 & 15 & 16.66 & 41 & 45.55 \\
\hline ii. & Aphid-jassids & $\begin{array}{l}\text { Use } 400 \mathrm{ml} \text { Malathion } 50 \mathrm{EC} \text { in } 250 \\
\text { ltr. Water per acre }\end{array}$ & 33 & 36.66 & 17 & 18.88 & 40 & 44.44 \\
\hline \multirow[t]{2}{*}{2.} & \multicolumn{8}{|c|}{ Chemical disease control } \\
\hline & $\begin{array}{l}\text { Name of } \\
\text { diseases }\end{array}$ & Control measures & & & & & & \\
\hline i. & Loose smut & $\begin{array}{l}\text { Seed treatment with } 2 \mathrm{gm} \text { Vitavax or } \\
\text { Bavistin or } 1 \mathrm{gm} \text { Raxil per kg seed }\end{array}$ & 21 & 23.33 & 13 & 14.44 & 56 & 62.22 \\
\hline ii. & Flag smut & $\begin{array}{l}\text { Seed treatment with } 2 \text { gm Vitavax or } \\
\text { Bavistin per kg seed }\end{array}$ & 19 & 21.11 & 9 & 10.00 & 62 & 68.88 \\
\hline iii. & $\begin{array}{l}\text { Powdery } \\
\text { mildew }\end{array}$ & $\begin{array}{l}\text { Spray } 800 \text { gm Karathane or Sulfex in } \\
250 \text { ltr. Water per acre }\end{array}$ & 48 & 53.33 & 20 & 22.22 & 22 & 24.44 \\
\hline iv. & Rust & $\begin{array}{l}\text { Yellow rust-Spray } 200 \mathrm{ml} \text { Propacona- } \\
\text { zole Brown rust -Spray } 800 \text { gm } \\
\text { Mancozeb } 250 \text { ltr. water/ acre }\end{array}$ & 66 & 73.33 & 16 & 17.77 & 8 & 8.88 \\
\hline v. & Karnal bunt & $\begin{array}{l}\text { Seed treatment with } 2 \mathrm{gm} \text { Thiram per } \\
\mathrm{kg} \text { seed }\end{array}$ & 21 & 23.33 & 5 & 5.55 & 64 & 71.11 \\
\hline \multirow[t]{2}{*}{3.} & \multicolumn{8}{|c|}{ Chemical weed control } \\
\hline & $\begin{array}{l}\text { Name of } \\
\text { weed }\end{array}$ & Control measures & & & & & & \\
\hline i. & $\begin{array}{l}\text { Broad leaf } \\
\text { weed }\end{array}$ & $\begin{array}{l}\text { Spray } 250 \mathrm{~g} 2,4 \text {-D or } 8 \mathrm{~g} \text { Metsulfuron } \\
\text { or } 20 \text { gm Affinity in } 250 \text { ltr. of water } \\
\text { per acre }\end{array}$ & 64 & 71.11 & 16 & 17.77 & 10 & 11.11 \\
\hline ii. & $\begin{array}{l}\text { Grassy weeds } \\
\text { (Phlarisminor } \\
\& \text { wild oat) }\end{array}$ & $\begin{array}{l}\text { Spray } 160 \text { gm Topik or } 13 \text { gm Leader } \\
\text { or } 400 \mathrm{ml} \text { Axial in } 250 \text { ltr. of water per } \\
\text { acre }\end{array}$ & 64 & 71.11 & 18 & 20.00 & 8 & 8.88 \\
\hline iii. & $\begin{array}{l}\text { Broad leaf } \\
\text { weed+Grassy } \\
\text { leaf weeds }\end{array}$ & $\begin{array}{l}\text { Spray } 16 \mathrm{gm} \text { Total or } 160 \mathrm{gm} \text { Atlantis } \\
\text { or } 160 \mathrm{gm} \text { Vesta in } 250 \mathrm{ltr} \text {. Water per } \\
\text { acre }\end{array}$ & 49 & 54.44 & 13 & 14.44 & 28 & 31.11 \\
\hline
\end{tabular}


Table.4 Respondents' adoption weighted mean score of various practices of wheat production technology by Afghan wheat growers $(n=90)$

\begin{tabular}{|c|l|c|c|}
\hline Sr. No. & \multicolumn{1}{|c|}{ Category } & Weighted mean score (1-3) & Rank order \\
\hline $\mathbf{1 .}$ & Preparation of land & 1.63 & IV \\
\hline 2. & Seed rate (kg/acre) & 1.73 & III \\
\hline 3. & Spacing & 1.50 & V \\
\hline $\mathbf{4 .}$ & Seed treatment & 1.48 & VI \\
\hline $\mathbf{5 .}$ & Fertilizers & 1.80 & II \\
\hline $\mathbf{6 .}$ & Irrigation requirement & 1.97 & I \\
\hline 7. & Plant protection measurement & 1.40 & VII \\
\hline
\end{tabular}

Table.5 Respondents' adoption weighted mean score of various practices of wheat production technology by Indian wheat growers $(n=90)$

\begin{tabular}{|l|l|c|c|}
\hline Sr. No. & Category & Weighted mean score (1-3) & Rank order \\
\hline 1. & Preparation of land & 2.89 & I \\
\hline 2. & Seed rate (kg/acre) & 2.02 & VI \\
\hline 3. & Spacing & 2.02 & VII \\
\hline 4. & Seed treatment & 2.10 & IV \\
\hline $\mathbf{5 .}$ & Fertilizers & 2.37 & II \\
\hline 6. & Irrigation requirement & 2.25 & III \\
\hline 7. & Plant protection measures & 2.09 & V \\
\hline
\end{tabular}

In case of chemical diseases control, 62.22 per cent of the respondents had no adoption followed by 23.33 per cent of the respondents had full adoption and only 14.44 per cent of them had partial adoption of chemical control of loose smut. About flag smut, 68.88 per cent of the respondents had no adoption followed by 21.11 per cent of the respondents had full adoption and 10.00 per cent of them had partial adoption of chemical control of flag smut. In case of powdery mildew, more than half of the respondents $(53.33 \%)$ had full adoption followed by 24.44 per cent of them had no adoption and 22.22 per cent of the respondents had partial adoption. About rust, majority of the respondents $(73.33 \%)$ had full adoption, 17.77 per cent of them had partial adoption and only 8.88 per cent of the respondents had no adoption of chemical control of yellow rust. 71.11 per cent of the respondents had no adoption followed by
23.33 per cent of them had full adoption and only 5.55 per cent of the respondents had partial adoption of chemical control of Karnal bunt disease in wheat crop.

Regarding chemical weed control, 71.11 per cent of the respondents had full adoption of recommended dose for chemical control of broad leaf weeds followed by 17.77 per cent of them had partial adoption and 11.11 per cent of the respondents had no adoption. 71.11 per cent of the respondents had full adoption of recommended dose for chemical control of grassy weeds followed by 20.00 per cent of them had partial adoption and 8.88 per cent of the respondents had no adoption of grassy weeds (Phlaris minor and wild oat). The recommended dose of chemical control for both broad and grassy leaf weeds, more than half of the respondents $(54.44 \%)$ had full adoption while, 31.11 per cent of them had no 
adoption and 14.44 per cent of the respondents had partial adoption of (broad leaf weeds + grassy leaf weeds) chemical weed control in wheat crop.

These findings are in conformity with the findings of Deshmukh and Tamgadge (2011). They reported that 68.67 per cent of farmers had fully adopted chemical control measures to control the stem borer, while Singh et al., (2014) reported that 96.88 per cent of wheat growers had adopted recommended dose of herbicides to control weeds and 42.50 per cent of them had adopted chemical control measures to control termite and aphid.

\section{Respondents' adoption weighted mean score of various practices of wheat production technology}

The data in Table 4 shows that respondents' adoption weighted mean score of various practices of wheat production technology in Afghanistan, ranged from 1.40 to 1.97 . Further, the recommended practices having highest mean score were irrigation requirement with rank I followed by fertilizers with rank II, seed treatment (kg/acre), preparation of land, spacing, seed treatment and plant protection measures were ranked III, IV, V, VI, and VII, respectively for Afghan wheat growers. It is concluded that irrigation requirement, fertilizers and seed rate $(\mathrm{kg} / \mathrm{acre})$ were most adopted practices than other practices, while plant protection measures, storage and seed treatment were less adopted practices of wheat production technology by Afghan wheat growers.

While in India, the data in Table 5 shows that the respondents' adoption weighted mean score of various practices of wheat production technology ranged from 2.02 to 2.89 . Recommended practices having highest mean score were preparation of land with rank I followed by fertilizers with rank II, irrigation requirement, seed treatment, plant protection measures, seed rate and spacing were ranked III, IV, V, VI and VII respectively for Indian wheat growers. Thus, it is concluded that recommended varieties, preparation of land, storage and fertilizers were most adopted practices than other practices in India, while spacing, seed rate and plant protection measures were less adopted practices for wheat production technology.

It is clear that there was low level of overall adoption of wheat production technology in Afghanistan and medium level in India, which might be due to their low and medium level of overall knowledge.

In conclusion the majority of the respondents $(87.77 \%)$ in Afghanistan had low level of overall adoption followed by only 12.22 per cent had medium level of overall adoption, while In India, 64.44 per cent of the respondents had medium level followed by 21.11 per cent had low and 14.44 per cent of the respondents had high level of adoption of wheat production technology in wheat crop. Further, the respondent's adoption weighted mean score of various practices of wheat production technology in Afghanistan ranged from 1.40 to 1.79 while that in India, the adoption weighted mean score of various practices of wheat production technology ranged from 2.02 to 2.89 . It is clearly indicating that Afghan farmers are far behind in adoption of various wheat production technologies. So, it needs much attention of Afghan government to formulate such policies for researchers, extension functionaries and other agencies which are working directly or indirectly with the Afghan farmers for boosting the wheat production in Afghanistan by applying various wheat production technologies. All stakeholders should be well equipped with all production technologies and inputs in terms of knowledge through latest media tools, 
improved seeds, fertilizers, pesticides and other natural resource management practices such as drip, sprinkler, bed planting methods of irrigation and other ways and means of transferring latest wheat production technologies among the Afghan farmers.

\section{References}

Anonymous (2017): Published by the Department of Agriculture and Farmer Welfare,

Haryana. www.agriharyana.gov.in.

Anonymous (2017): Published by the Food and Agriculture Organization (FAO) STAT. www.fao.org.

Anonymous (2018): Progress Report of All India coordinated Wheat and Barley Improvement project 2017-18, Director's Report, Ed. G.P ICARIndian Institute of Wheat and Barley Research, Karnal, India.

Anonymous (2018): Published by the Department of Agricultural, coorperation and Farmer Welfare, Government of India. www.seednet.gov.in.

Anonymous (2018): Republic of Afghanistan Ministry of Agriculture, Irrigation and Livestock, Department of Agriculture statistic data arrangement.

Deshmukh, A.S. and Tamgadge, S.B. (2011): Adoption of paddy growers about recommended technology. Agriculture Update. 6 (1): 81-84.
Kumar, N. (2019): Knowledge and adoption of seed production technology of wheat in Haryana. M.Sc thesis, Chaudhary Charan Singh Haryana Agricultural University, Hisar.

Kumbhare, N.V. and Singh, K. (2011): Adoption behaviour and constraints in wheat and paddy production technologies. Indian Research Journal of Extension Education, 11 (3): 41-44.

Meena, B.S. (2012): Adoption behaviour of wheat production technology, Agriculture Update. 7 (3/4): 283-286.

Patodiya, R.S. (2018): Knowledge and adoption of scientific wheat cultivation practices in Rajasthan, Indian Research Journal of Extension Education, 18 (1): 93-95.

Singh, D. and Dhillon, D.S. (2006): Communication behaviour of agricultural development officers of Punjab, Annals of Biology, 22 (1): 6774.

Singh, K., Singh, P. and Lakhera, J.P. (2012): Constraints in adoption of wheat production technology perceived by small farmers, Rajasthan Journal of Extension Education, 20: 112-116.

Singh, R, Hansra, B.S. and Chand, R. (2014): Knowledge and adoption level of farmers of Haryana about scientific wheat cultivation practices. Indian Journal of Agricultural Research, 48 (1): 52- 56 .

\section{How to cite this article:}

Abdul Rashid Mukhtarzai, P. K. Chahal and Ghanghas, B. S. 2020. A Comparative Study on Wheat Production Technology Adopted by Indian and Afghan Farmers. Int.J.Curr.Microbiol.App.Sci. 9(08): 3556-3568. doi: https://doi.org/10.20546/ijcmas.2020.908.410 